\title{
๑LUMEN Proceedings
}

Available online at:

http://proceedings.lumenpublishing.com/ojs/index.php/lumenproceedings

10th LUMEN International Scientific Conference Rethinking Social Action. Core Values in Practice | RSACVP 2018 |

20-21 April 2018 | Suceava, Romania

\section{Rethinking Social Action. Core Values in Practice}

\section{Economic Laws, Necessities or Obstacles for Growing Companies?}

\author{
Valentin CALINOVICI
}

https://doi.org/10.18662/lumproc.34

How to cite: Calinovici, V. (2018). Economic Laws, Necessities or Obstacles for Growing Companies?. In A. Sandu, T. Ciulei, (eds.), Rethinking Social Action. Core Values in Practice (pp. 49-57). Iasi, Romania: LUMEN Proceedings. https://doi.org/10.18662/lumproc.34 


\author{
$10^{\text {th }}$ LUMEN International Scientific Conference \\ Rethinking Social Action. Core Values in Practice \\ RSACVP 2018 | 20-21 April 2018 | Suceava-Romania
}

\title{
Economic Laws, Necessities or Obstacles for Growing Companies?
}

\author{
Valentin CALINOVICI ${ }^{1}$
}

Abstract

The objective of this paper is to discuss about economic laws in relation with companies development. They surely exist in every country, in different manners. It is important to understand if they are really important in the process of developing a company, or they are simply obstacles. In 2001, Enron was recording the biggest bankruptcy, at that moment, in the US A bistory. Soon after that, Sarbanes-Oxley Law was implemented very quickly for all the companies in USA. The purpose of the law was to avoid another similar case of Enron to happen in the American economy. But was that fair for all other thousands of companies from SUA to be obliged to pay for the implementation of such a drastic law? Up until this law exists, most of them had a good trajectory of development, not to mention that they were ethical and legal in procedures. It is important for a company to have laws created by the state in order to have a good development? Where is the liberty offered by the state to companies in order to develop in a libertarian manner? Is there any? In this project I want to discuss about the importance of the Sarbanes-Oxley law in $S U A$ based on empirical data collected from different books and specialist analysis. The aim of this paper is to emphasize the importance of the economic laws for the life of a company in a long term vision. In particular, I will argue that the economic laws can be considered obstacles and necessities.

\section{Keywords:}

Economic laws, company, development, long-term vision, framework

\footnotetext{
1 PhD student, Faculty of Philosophy, University of Bucharest, Romania, calinovici.valentin3@gmail.com
} 


\section{Introduction}

Throughout history, human civilization has developed in a rate sustained by laws and rules who contributed at the cementation of the development context. Some laws proved to be useful, but especially necessary as the negative consequences of human activities have multiplied. In this new millennium, our world had become very complex with laws in all kind of domains of our life, like ecology, economy, literature, construction and even travel. In the following lines I would like to analyze the relevance of laws in relation to business. Companies aren't insignificant factors that contribute for the good course of the economy and for this reason it is important to understand the binder between them.

The variety of business domains and the diversification of human needs led to a wide market where companies have the perfect framework in order to do business and to develop. So those economic agents have multiplied in the same time with the growing population. Companies have become important pawns as for the local economy as well as for the macro economy, so that it was necessary to create a legislative framework that would direct the companies' development towards an optimal cost / benefit ratio. So, after consultations with companies and after finding certain needs, the countries created economic laws that would smooth the proper functioning and development of the companies. In the following lines I will analyze the correctness of the utility report in the law-making process between the state and the business environment.

Often there is a conflict between state institutions and companies due to the legal framework created. The emphasis in this work is on the utility of these laws. Yearly, new laws are emerging as a result of the development of economic activity. Most companies, on their way to development, find new challenges in law. However, laws have the role of drawing the idea of good and highlighting the trajectory of the economy. The idea of a good economy is based on moral values that are part of or should be part of the acoustic actions. But, moral values can or can not be respected. The main question that the state puts in is closely related to the idea of well: how can we ensure that the precepts of the idea of good in the economy are respected?

The structure of this paper is the following: I will start by presenting the facts in section 1. In section 2 I will examine the issue of the SarbanesOxley law and in section 3 I will present the utility of this law. Finally, I will end with some final remarks. 


\section{The state of the matter of economic legislation}

Up until 2001, the political class created laws aimed in supporting the development of the economy, putting too few control limits. A single bankruptcy with multiple consequences has led the political class to create restrictive laws for all companies.

"Sarbanes-Oxley appeared as a legislative consequence, following the bankruptcy of Enron, on December 2, 2001" [7]. At that time, it was considered the biggest bankrupt in US history. This law proved necessary, given that the legislative context was very poorly regulated and allowed for certain financial records to be made using registration methods that did not suitably fit in the field of Enron activity. But Enron, using these legal loopholes, knowingly concealed some of the losses in some of the projects and declared a partially veritable situation of the company's overall financial status. This method of financial reporting was permitted with the approval of the Financial Supervisory Authority.

About this case, the literature abounds in debates and arguments in an attempt to understand the importance and especially the restrictive nature of the laws. I mention among the authors Mihaela Dumitrascu with Corporate Governance and Corporate Social Responsibility, the Pillars of Sustainability, Nick Dauber with Auditing Standards, Scott Green with Manager's Guide to the Sarbanes - Oxley Act and Marcel Ghita with Guvernanta Corporativa. Corporate governance plays a very important role in the development of a company, and I believe it is up to the state to allow the growth of a company at a safe, transparent and sustainable pace.

Enron's bankruptcy has revealed gaps in the law that led the political class at that time through representatives of Paul Sarbanes, Senator and Michael G. Oxley, member of the House of Representatives, to counteract companies' opportunities to circumvent or misrepresent situations it's financial. The law did not address to all companies but only to those listed on the stock exchange and had a much greater influence among investors or employees in the event of bankruptcy.

The law, not very voluminous but otherwise well-structured, was subdivided into 11 sections that gave more power to the state and its authorities in exercising control over the companies. In short, I will remember the 11 sections of the law:

1. "Founding of a new supervisory board, called the $P C A O B$ - The Public Company Accounting Supervisory Commission, by which the state followed with new instruments added by this law that audit firms would provide clear, more transparent, and much more qualitative services" [12]. This new 
commission sets new standards for consultancy and audit firms to make them offer high-quality services and to prevent their complicity in the event of bankruptcy of the counselling firms.

2. "In order to avoid conflicts of interest, emphasis was placed on the independence of audit firms. Until the founding of this law, an audit and consulting firm was not legally prevented from providing an advised firm with both audit services over its business activities and consulting in business development" [12].

3. "Corporate Responsibility is a section that clearly delimits the responsibility of the Chief Executive Officer or Chief Financial Officer in assuming responsibility for the financial statements reported to the State " [12].

4. "Consolidated financial information provided by companies in clearly defined timelines and with the ability to be subject to rigorous scrutiny by the authority of the Securities Lending Commission, an institution representing the interests of the state for the companies listed on Stock Exchange" [12].

5. "The conflicts of interest of financial analysts employed by the company represented a point in the law that increased their reporting powers to the state over their work. In practice, if they would identify issues that could jeopardize the proper development of the company they were working for, they would no longer respond to direct managers who could have influenced their decision, but could break the secret of service and report to state institutions if they thought that the analyzes were of a perilous nature to the company or its investors" [12].

6. "The authority and resources of the Security Exchange Commission, an institution that could perform controls and oversee companies listed on the US Stock Exchange, were supplemented in accordance with the state's expectations regarding the avoidance of possible bankruptcy" [12].

7. "Periodic studies and reports made by Security Exchange Commission, through which this institution undertakes to conduct with the appellant in order to be able to mirror the company's image in relation to the independent studies and reports produced by the commission annually" [12].

8. "Corporate responsibility and fraudulent accounting is a law that also labelled the "Corporate and Fraud Accountability Law of 2002". This section of the Sarbanes-Oxley draws penal sanctions that could get companies who knowingly destroyed, manipulated or altered financial information" [12].

9. "White-collar crime penalty enhancements is the section of the law that shades more clearly what facts are being criminally criminalized, with 
emphasis on how to submit the financial information and on the truthfulness of the information submitted" [12].

10. "Corporate Tax Return is the penultimate section of the law that treats the responsibility of the Financial Director who should be equally responsible for corporate tax returns with the entity for which he works" [12].

11. "Corporate responsibility for fraud is the last section of the law that also bears the name of the "Corporate Responsibility Act 2002". This last section identifies and delimits the actions of fraud and establishes punishments that may be applied for their violation" [12].

\section{The problematic issues of the law}

For the mistakes made by Enron both in financial reports, influencing financial analysts for misrepresentation, and influencing complicity of business partners to fraud and false statements, "the SarbanesOxley Act had the political support of both the House of Representatives, the American Senate as well as the US President of those times, George W. Bush in moving very fast towards implementation "[10]. The law, given the context of Enron's bankruptcy, did not have much time to debate between state institutions and business. This has generated a wave of business dissatisfaction that has called for the law to be repealed. "These attempts to cancel have also crystallized in 2018 , but so far, no decision has been made yet" [1].

The problematic aspect of the law lies in the multitude of companies that have had unpretentious conduct with the state authorities both before Enron bankruptcy and after the implementation of the Sarbanes-Oxley law to date. For these companies, the implementation of the law came with a cost, which the representatives of the companies see as unnecessary. "Listed companies have reached a cost of one million dollars annually spent on implementing the law, while small companies reach expenses 500000 dollars annually" [11]. "Moreover, many smaller companies but with great opportunities to grow, who did not consider implementing the law in the company code of conduct, choose listing on the stock exchange in London, to the detriment of the Stock Exchange in New York City, which is under the Sarbanes-Oxley Law" [2]. Besides the costs of law enforcement, there are costs of observing controls and periodic reports to the Securities Commission, where companies have been forced to invest a lot of resources.

"In a World Bank study, if by 2001 the US occupied only the 20th position in the list of states that protected investors from the potential risks they might have through their system of laws. Starting with the 
implementation of the Sarbanes-Oxley law, investors have gained more confidence in US policies, so that in 2007 the US position climbed 13-fold to $7^{\text {th" }}[13, \mathrm{p} .34]$. If small businesses started to lobby for repeal of the law, due to their restrictive and costly nature, intergovernmental organizations such as the OECD have advocated greater law-making for companies, while maintaining law. Thus, even governmental voices believed the law had issues that could be improved but did not support the annulment of the law. The OECD argued that the relationships between investors and company directors had to be improved and could have done so only through the law. This intergovernmental organization has argued that "a more prolific relationship between the state and companies should be maintained, or it could be made more transparent by having more and more detailed internal audit controls that ensure corporate responsibility in the relationship have with the investors" [4].

Although for the representatives of the political class, this law was a means of additional protection for the state, investors and employees of these companies, "for US companies, the law was seen as a legal barrier" [6]. Its utility has also been seen by other states such as Canada, France, Germany, Japan, Italy or Australia that have implemented them on their territory with the changes that have been made necessary because of the particular character of each state.

This law was perceived as a means of protection by investors, but for companies it was perceived as costly and like a new legislative burden. Thus, most companies wondered if this law is really useful and necessary.

\section{The utility of the Sarbanes Oxley law}

Any company that wants to share profits now analyze the legal framework and, after a series of calculations and predictions made, choose to conduct business in that state. Every company's standards must be as high as possible in complying with the laws imposed on it so that the aim is to reconcile with the methods used. The purpose of the laws has been since the creation of the first constitutions to meet the needs of the people and to provide them with the necessary support for development. The US state created the Sarbanes-Oxley Act because it did not want an Enron expansion bankruptcy that has generated so much loss of resources ever to happen.

Do companies deserve more freedom to allow them to work as freely as possible?

I believe that no democratic state is very restrictive with the activity of commercial agents, but on the contrary supports it with all the legal instruments available so that the company can develop in the best possible framework. Both companies and the state are responsible for the freedom 
they have at their disposal. "Corporate governance must respect two dimensions to sustain its development, namely:

- The behavioural dimension, which implies the rallying of the investors' expectations with those of the company's employees and of the clients;

- The normative dimension, which involves the merging of development policies with the laws of the state; [4].

Freedom is useful and offered to companies within the limits that each state considers sufficient. The laws that companies have in their role are to provide a justification for their development and to punish possible actions that would exceed their spectrum of activity. In the absence of laws, if there were bad malpractice by firms, like the Enron case who knowingly chose to hide real financial statements from state institutions; it could generate significant losses for the parties involved. Businesses have the freedom to operate freely, but they need to be aware of possible slippages. For the state it is important to have a sustainable relationship with the companies, in which the involved parties, clients - shareholders - state, have to win. "In order to ensure this prolific relationship, the state must offer companies freedom of development with precautions in the event of mistakes or errors" [5, p. 24].

Why are there so many restrictive laws and all the more so because there are laws like Sarbanes - Oxley, as the state encourages companies' activity?

I believe that the state cannot act in front of companies as if they were acting in good faith in doing their business, because the state is not only responsible for the good functioning of these companies but also for investors, employees and public opinion. Therefore, the laws created by the state should be seen as necessary in building a transparent, honest and discouraging legislative framework for those entities that try to cheat employees, partners or even the state. Laws have become increasingly restrictive as offenses have multiplied. Therefore, companies are encouraged, just as they did before the promulgation of the Sarbanes-Oxley Act, to develop and be as active as the state must be aware of the accuracy of their actions.

\section{Is the Sarbanes - Oxley law useful?}

I believe that if the Sarbanes-Oxley Act had been in force before December 2, 2001, the chances that Enron had gone bankrupt would have been significantly reduced, resulting in the loss of approximately 20,000 jobs, the loss of pension funds millions of people "(eg former Enron employees who in the number of 20,700 have claimed in court the recovery of the invested damage amounting to around one billion dollars)" [9]. "By this law 
it was intended to limit the legislative deficiencies and to highlight the importance of the prevention of the company's good development." [3].

\section{Conclusions}

The aim of this paper was to emphasize the importance of the economic laws for a business company. I have discussed about the problems that occurred immediately after the law came into being and the legal facts stated by the current legislation. The importance of these ideas lies in the very nature of the Sarbanes-Oxley law, which was accepted and modified by zonal specificity, and by other states outside the United States. At international level, the contribution can be applied predominantly in the legislative debates of certain bills. In recent years, there has been a growing disparity between state institutions as well as commercial companies or other entities, which generates tension and even unfavorable consequences. For a good state function, I believe that laws must be debated before being promulgated with all the particles involved to understand their need. Or, if a problem has been properly addressed by laws in a particular state, I consider it more than appropriate that both the method and the good influence of that law should be enjoyed by other states.

For most law enforcement companies, the implementation of the law involved only an extra cost of resources. With this additional cost, the US State has tried to prevent opportunities for businesses such as Enron or WorldCom to go bankrupt and generate far greater losses than companies need to invest in law enforcement. For the US State, it was sufficient to find a loophole exploited incorrectly and legally by a single company to counter the possibility of repeating bankruptcy of colossal proportions by other companies. In the absence of this law, situations similar to Enron could not have been restricted or prevented.

\section{References}

[1] .Brady M. Will president trump repeal Sarbanes-Oxley? 2018. Retrieved from:

https://www.mbradylaw.com/kansas-city-whistleblower-lawyerblog/2018/01/11/will-president-trump-repeal-sarbanes-oxley/

[2]. Clark H. Sarbanes-Oxley Goes Global; 2006. Retrieved from:

https://www.forbes.com/2006/07/13/leadership-sarbox-governance-

cx hc 0713sarboxgoesglobal.html\#743d468d65c0 
[3]. Dauber N., Qureshi A. A., Levine H. M, Siegel G. J. Auditing standards including the Standards of the PCAOB, Thompson Publishing House, Crawfordsville; 2005.

[4]. Dumitrascu M. Corporate Governance and corporate social responsibility, the pillars of sustainability, ASE Publishing House, Bucharest; 2015.

[5]. Ghita M. Guvernanta corporativa, Bucharest, Economica Publishing House; 2008.

[6]. Green S. Manager's Guide to the Sarbanes-Oxley Act, John Willey and Sons LTD Publishing House; 2004

[7]. Masters B. Enron fails raised the bar in regulation; 2011. Retrieved from: https://www.ft.com/content/9790ea78-1aa9-11e1-ae14-00144feabdc0

[8]. Morgenson G. Sarbanes-Oxley, Bemoaned as a Burden, is an Investor's Ally. Retrieved from: https://www.nytimes.com/2017/09/08/business/sarbanesoxley-investors.html

[9]. Paulsen S. Workers lose jobs, health care and savings at Enron; 2002. Retrieved from: https://www.wsws.org/en/articles/2002/01/enro-j14.html

[10]. Peregrine M. Sarbanes-Oxley changed America; 2012. Retrieved from: https://www.nytimes.com/roomfordebate/2012/07/24/has-sarbanesoxley-failed/sarbanes-oxley-changed-corporate-america

[11]. Thompson M. The Effects od Sarbanes-Oxley on small business: more than you might think; 2017. Retrieved from:

https://www.business.com/articles/the-effect-of-sarbanes-oxley-on-smallbusiness-more-than-you-might-think/

[12]. Sarbanes-Oxley Act, 2002. Retrieved from: http://www.sarbanes-oxley101.com/sarbanes-oxley-toc.htm

[13]. World Bank, Doing Business, Washington D.C., 2008. 